\title{
Helping among kin vs. non-kin: The role of psychological closeness
}

Ferolino, Austin

University of San Carlos, Philippines (aferolino@usc.edu.ph; austinferolino@hotmail.com)

Labaclado, Richie

University of San Carlos, Philippines (richielabaclado@gmail.com)

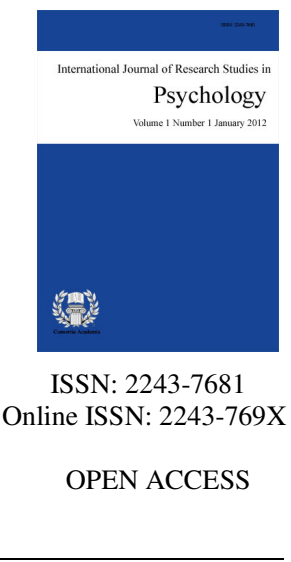

\section{Abstract}

This study explored the patterns of helping directed to kin versus non-kin. The participants of the study were 270 undergraduate students recruited from online and regular class periods. Moderated regression analysis confirmed that psychological closeness moderates the relationship between perceived kinship status and willingness to help. Specifically, the relationship between closeness and helping increased for non-kin, but decreased for kin. Results may imply that psychological closeness is an important determinant in helping a non-kin, and less important in helping a kin.

Keywords: psychological closeness; moderation; willingness to help 


\section{Helping among kin vs. non-kin: The role of psychological closeness}

\section{Introduction}

The general rule of kin altruism is that humans help kin more than non-kin, which is largely driven by kin selection (Hamilton, 1964). However, there are instances where individuals are more than willing to help non-kin than kin (Essock-Vitale \& McGuire, 1985; Kruger, 2003). Generally speaking, evolutionary explanations of these patterns of prosocial behavior across kin and non-kin seem equivocal. Kin selection theory seemed to overlook the psychological bond between the helper and the recipient. Clearly, there's a need to investigate what other substantial underlying mechanisms of why one is more than willing to help a non-kin than to a kin. For instance, sense of oneness, which is an outcome of relationship closeness, found to be a predictor of self-report helping (Maner, Luce, Neuberg, Cialdini, Brown, \& Sagarin, 2002). Hence, the present study examined the role of psychological closeness on the willingness to help a kin vs. non-kin, which can be merged with Kin selection theory (KST).

\subsection{Willingness to help a kin vs. non-kin}

People dedicate their time and energy to help based on the help seeker's kinship status (i.e., kin vs. non-kin). Most people prefer genetically closer kin over non-relatives (Burnstein, Crandall, \& Kitayama, 1994; Neyer \& Lang, 2003; Stewart-Williams, 2008). KST suggests that a gene causing its bearer to act altruistically provided that the benefits conferred on these relatives outweigh the costs incurred by the bearer. For instance, several studies validated that people in diverse societies preferably help close kin over more distant kin and non-kin (e.g., Betzig, 1988; Betzig \& Turke, 1986; Chagnon \& Bugos, 1979; Chagnon, 1981; Flinn, 1988; Gurven, Hill, Kaplan, Hurtado, \& Lyles, 2000; Hames, 1987; Hawkes, 1983; Patton, 2005; Pollet, Roberts, \& Dunbar, 2013).

There are situations, however, when altruistic acts are directed more to friends than family. For instance, Essock and associates (1985) pointed out that women tend to be more inclined to help friends than blood-related family members. Korchmaros and Kenny (2001) yielded comparable results when they showed that individuals were more willing to help their spouses than their genetically-related relatives. Based on evolutionary principles, one reason why people help their non-kin is because of inferred genetic-relatedness as implicitly cued by familiarity, similarity, friendship, and emotional experience of empathy (Neuberg, Kenrick, \& Schaller, 2010). For example, Studies illustrated how similarity and familiarity promotes trust, thus, promotes cooperative behavior (Krupp, DeBruine, \& Braclay, 2008; Hoffman, 1981; Krebs, 1987; Park, Schaller, \& Van Vugt, 2008). In other words, KST suggests that that non-kin altruism will only occur if there is some benefit for the member of the group who is performing the altruistic act or if it is a benefit for one or more of the altruistic member's kin. Some members of non-kin groups will still receive just as much, if not more help, than an individual who is genetically related to the person who is engaging in altruistic behavior.

\subsection{Psychological closeness and willingness to help}

People normally cultivate friendship or enduring and selective social bonds in which partners help each other in times of need, often at great cost to themselves. Researchers on close relationships proposed various explicit definitions of closeness. The self-expansion theory contends that individuals' sense of self can be widened to incorporate others, and will probably come about when these others are individuals we feel close to (Aron, Aron, Tudor, \& Nelson, 1991). In this study, the definition of closeness is built out of the essential features of interdependent close relationship. These features comprise of the degree of interdependence, proximity, emotional dependence, and incorporation of self and the other (Clark, Oullette, Powell, \& Milberg, 1987). This sense of shared identity termed as "oneness" (Cialdini, Brown, Lewis, Luce, \& Neuberg, 1997). Also, when people take their perspective and put themselves in others' shoes is a sense of psychologically close to 
others (e.g., Gunia, Sivanathan, \& Galinsky, 2009). According to these lines of research, self-other overlap is an outcome of relationship closeness. Researchers proposed that the merging of self and other identity is most likely conditions linked to the empathy-altruism model to feelings of attachment and altruistic motivation (e.g., Davis, Conklin, Smith, \& Luce, 1996). Building on this, a sense or felt of 'oneness' with others reflects a desire to maintain a mutual responsive relationship, thus, predicts willingness to help closer others in need (e.g., Clark \& Lemay, 2010).

\subsection{Psychological closeness on willingness to help kin vs. non-kin}

The discussion above points out that some individuals differ in levels of acting altruistically towards a target kin vs. non-kin. KST cannot fully stipulate for a tidy explanation of this phenomenon. Conversely, these instances might be clarified by the reciprocity rule. When it comes to friendships, helping more a friend than a family can be explained by reciprocal altruism (e.g., Trivers, 1971). It's the tendency to help non-kin based on a likelihood of return. Reciprocal altruism is less significant among kin than among non-kin, because the indirect fitness benefits of helping kin can overshadow the direct fitness costs of unreturned help (Hamilton, 1964). However, some researchers suggest that reciprocity does not account for a satisfactory explanation for altruism among friends (e.g., Roberts, 2005; Silk, 2003; Tooby \& Cosmides, 1996). Interestingly, Stewart-Williams (2007) showed that people help friends more than blood-related family members with low-cost of helping; they help blood-related family members and friends equally with medium-cost of helping, and they expressed greater willingness to help siblings than friends with higher cost of helping. By some means, the study clarifies the proximal causes that lead to pattern differences among kin vs. non-kin with regard to acting altruistically. However, the study pointed out that cost-of-help results may perhaps be clarified similarly well with cultural norms, with which individuals provided more high-cost help to kin than to friends because they experience stronger normative pressure to do so (e.g., Jocano, 1998). Thus, the study does account for a clear psychological mechanism that answers this peculiarity in light to KST's general rule. It's plausible that these results may be explained by the proximate cause of psychological closeness. Thus, the researchers hypothesized psychological closeness may not be a necessary condition of acting altruistically towards a kin; however, it a does play a role when help is directed to a non-kin. In other words, there will be higher levels of willingness to help among non-kin than among kin because kinship reduces the need for closeness in accordance with KST's general rule.

\section{Method}

\subsection{Research Design}

The study is quantitative in design and utilized a survey method wherein respondents completed set of scales determining their psychological closeness, perceived kinship status, and willingness to help. In terms of the perceived kinship status, different set of respondents filled up the form for kin recipient whereas another set of respondents completed the form for non-kin

\subsection{Participants}

The participants of the study were two hundred seventy (270) undergraduate students recruited from three universities in the Philippines. There were one hundred seventy (63\%) participants recruited online from the pool of undergraduate psychology students and received course credit for their participation. One hundred (37\%) participants were recruited from regular class periods in school.

\subsection{Instruments}

The study utilized two (3) research instruments, namely: kinship status texts, the level of closeness scale and self-report helping scale. 
Ferolino, A., \& Labaclado, R.

Perceived Kinship Status - There were two sets of questionnaires, with which participants were asked to imagine either a kin or a non-kin. The researchers dummy coded non-kin as 0 and kin as 1 in the analysis of data.

Level of Closeness Questionnaire - The items that assessed the level of closeness were constructed based on the important properties that characterize highly interdependent close relationships. These include frequency of contact and shared activities (Kelly et al., 1983; Bercheid, Snyder, \& Omoto, 1989), feeling close (Aron, Aron, \& Smollan, 1992) or emotional closeness (Rhee, Uleman, Lee, \& Roman, 1995), and behaving close (Aron, et al., 1992). A number of items were also adapted from the Relationship Closeness Inventory - item no. 6 (Bercheid et al., 1989) and Relational interdependence - items no. 4, 24, 28, and 37 - (Rhee et al., 1995). Closeness here depicts the interconnectedness of the self and the other (Aron et al., 1991). The Questionnaire was modified to fit the study's context. The modified version reported a high internal consistency $(\alpha=.936)$.

Self-Report Altruism Scale (SRA) - This scale has an easy-to-administer, self-report format and consists of 20 items (Rushton, Chrisjohn, \& Fekken, 1981). The scale was developed to measure unconditional everyday altruism, with internal consistency of Cronbach's $\alpha=0.79$. The SRA scale determines the participants' likelihood of performing certain behaviors for a variety of related and unrelated individuals. The researchers modified the scale, so that each question is concerned with participants' altruistic tendencies toward a kin and non-kin. There were two modifications made. The first modified scale measures the participants' helping behavior directed to a kin, with Cronbach's $\alpha=.78$. The second modified scale measures participants' helping behavior directed to a non-kin, with Cronbach's $\alpha=.93$. The 20 items of the scale stated everyday altruistic behaviors (e.g., giving small amounts of money without expecting to get it back or buying gifts without concern for receiving gifts in return), which frequency respondents were instructed to rate (from $1=$ never, to $5=$ very often).

\subsection{Procedure}

Participants were run by that the anonymity and confidentiality of the study. They were encouraged to ask for clarifications from the questionnaire by researchers throughout the process of data collection. Questionnaires were administered by means of online and during a regular class period. One hundred and seventy (63\%) participants completed the online questionnaires focused to kin. Whereas, one hundred (37\%) participants completed the pen and paper questionnaires focused to non-kin in regular class periods. Incentives were given after completing the form.

\subsection{Data Analysis}

To look into the relationship of psychological closeness and willingness to help a kin vs. non-kin, Pearson's correlation was used. Moreover, hierarchical regression analysis was conducted in order to examine the moderating effects of perceived kinship status in the link between closeness and willingness to help.

\section{Results}

\subsection{Descriptive and Bivariate Analysis}

The means and standard deviations of the participants' perceived kinship status to the recipient (i.e., kin or non-kin), closeness and helping behavior were reported in Table 1. Also, Pearson's $r$ correlation between variables was presented in Table 1. As shown, closeness did not correlate with willingness to help $(r=.08, p$ $=.476)$ for kin as perceived recipients, but showed significant correlation with willingness to help for non-kin recipients $(r=.41, p<.01)$. Initially, these correlational results confirmed the study's hypothesis. 
Helping among kin vs. non-kin: The role of psychological closeness

Table 1

Correlation between variables including Means and Standard Deviations

\begin{tabular}{llllll}
\hline Recipient & \multicolumn{1}{c}{ Variables } & Mean & SD & 1 & 2 \\
\hline Kin & & & & & \\
& Psychological Closeness & 5.4 & 1.1 & & $.41^{* *}$ \\
\multirow{3}{*}{ Non-Kin } & Willingness to help & 3.1 & 0.4 & $.41^{* *}$ & \\
& & & & & \\
& Psychological Closeness & 5.3 & 0.6 & & .08 \\
& Willingness to help & 5.4 & 1.0 & .08 & \\
\hline Note. $* p<.05, * * p<.01$ & & &
\end{tabular}

\subsection{Moderated Regression Analysis}

A hierarchical regression model was utilized to investigate whether the link between psychological closeness and willingness to help depends on the perceived kinship status (i.e., kin vs. non-kin). Moderation occurs when the association between an independent variable and dependent variables changes as a function of the moderator variable (Baron \& Kenny, 1986). In this study, moderation means that the slope of the relationship between the independent and dependent variable differs across the groups represented by the categorical moderator variable (e.g., Aguinis, 2004; Jaccard \& Turrisi, 2003; Jose, 2013). To avoid potentially problematic high multicollinearity with the interaction term, the variables were centered and an interaction term between closeness and kinship status was created (Aiken \& West, 1991).

Table 2

Summary of Moderated Regression Analysis (N=270)

\begin{tabular}{llll} 
& \multicolumn{1}{c}{ Predictor } & \multicolumn{2}{c}{ Willingness to Help } \\
\cline { 3 - 4 } & & $\Delta \mathrm{R}^{2}$ & \multicolumn{1}{c}{$\mathrm{B}$} \\
\hline Step 1 & Psychological Closeness & .025 & $.079^{* *}$ \\
Step 2 & Psychological Closeness & & $.079^{*}$ \\
& Kinship Status & .025 & .021 \\
Step 3 & Psychological Closeness & & $.362^{* * *}$ \\
& Kinship Status & & -.001 \\
& Closeness x Kinship Status & .063 & $-.341^{* * *}$ \\
& Total $\mathrm{R}^{2}$ & .088 & \\
\hline Note. ${ }^{*} p<.05 . * * p<.01 . * * p<.001$ & &
\end{tabular}

The hierarchical regression analysis revealed that at Step one, psychological closeness significantly predicted willingness to help $(\beta=.079, \mathrm{p}<.01)$. In Step two, psychological closeness significantly predicted willingness to help $(\beta=.07, p<.05)$, but not kinship status kinship status help $(\beta=.021, p=.739)$. In the step 3 , the interaction term between closeness and kinship status was added to the regression model, which accounted for a significant proportion of the variance in willingness to help, $\Delta R 2=.062, \Delta F(1,266)=9.318, p<.001, b=$ $-2.168, t(266)=4.278, p<.001$. Thus, this indicates that the link between psychological closeness and willingness to help depends on the perceived kinship status. Furthermore, the significant negative interaction effect indicated a buffering effect that increasing kinship status (i.e., kin) would decrease the effect of the closeness on willingness to help.

\section{Discussion}

Several studies showed that subjective or emotional closeness coined as an underlying mechanism of genetic relatedness, which is also inclusive to other forms of social relationships to help across kin and non-kin relations (Korchmaros \& Kenny, 2001, 2006). Interestingly, the results of the study displayed a different bearing. The link between psychological closeness and willingness to help tend to buildup, if recipient is non-kin, but decline if kin. This may imply that closeness may characterize, among other things, proximate cue to genetic relatedness, thus, predicts helping among non-kin. Thus, people develop concern for others' welfare when interdependence 
increases.

On the other hand, closeness may not be an important proximal mechanism if help is directed to a kin (family members). By some means, this study confirms the general rule of KST, with which individuals are inclined to help family members strongly based on shared genes (Rushton, Russell, \& Wells, 1984; Wells, 1987; Webster, 2003). With this, blood ties are more vital compared to subjective or felt connection between family members when it comes to increasing prosociality.

The study includes a continuous measure of closeness, rather than conflating social relationships and closeness. More importantly, this research also uses a non-western sample, which is unusual in this area of research. The importance of kin relationships appears invariant across the diverse cultures of the human species (Neyer \& Lang, 2003). In a Filipino society, the expectations and relationships among family member are highly distinct from one's relationships with non-family members (Jocano, 1998). The self and social identity of Filipinos; greatly from their blood ties, which also function as key foundation of financial, social, emotional and moral support (Miralao, 1997). With this, Filipinos learn the value of keeping their identities as a family member intact. This is further reinforced by a continuous flow of help, assistance, and favors among relatives.

Despite these noteworthy discussions, it is highly important to mention the drawbacks of the study. First, a more refined research design and data collection method should be employed to yield better significant results. For an instance, priming closeness and kinship status cues, and helping tasks should also be employed to strengthen the ideal relationships. Second, besides using self-report altruism rating scale, recorded free responses to a scenario presented in a paragraph could also be used, as it would reflect how the participants think, thus, giving a more accurate cognition on their willingness to help. Third, additional processes should be included in preference giving toward across kin and non-kin throughout the assessments of the relationship closeness model. Lastly, additional effort should be employed which examines the specific cognitive and physiological factors mediating cues of kinship and friendship relations will help us realize how such cues are managed.

\section{Conclusion}

This study explored the role of psychological closeness on willingness to help a kin vs. non-kin. General results provide an alternate view of why patterns of helping differ across kin and non-kin relations. Specifically, the relationship between closeness and helping increased for non-kin, but decreased for kin. Results may imply that closeness is an important determinant of prosociality for friends, and may be less important for blood-related family members. Closeness is sufficient for friends, but not for blood-related family members. Perhaps, in helping situations, blood is thicker than water after all.

Acknowledgement: This paper was presented at the $51^{\text {st }}$ Annual Convention of the Psychological Association of the Philippines (PAP).

\section{References}

Aguinis, H. (2004). Regression analysis for categorical moderators. New York, NY: Guilford Press.

Aiken, L. S., \& S. G. West (1991). Multiple regression: Testing and interpreting interactions. Newbury Park: Sage Publications.

Aron, A., \& Aron, E. N. (1986). Love and the expansion of self: Understanding attraction and satisfaction. Washington, DC: Hemisphere.

Aron, A., Aron, E. N., \& Smollan, D. (1992). Inclusion of other in the self-scale and the structure of interpersonal closeness. Journal of Personality and Social Psychology, 63, 596-612. http://dx.doi.org/10.1037/0022-3514.63.4.596

Aron, A., Aron, E. N., Tudor, M., \& Nelson, G. (1991). Close relationships as including other in the self. Journal 
Helping among kin vs. non-kin: The role of psychological closeness

of Personality and Social Psychology, 60, 241-253. http://dx.doi.org/10.1037/0022-3514.60.2.241

Baron, R. M. and Kenny, D. A. (1986). The moderator-mediator variable distinction in social psychological research - Conceptual, strategic, and statistical considerations. Journal of Personality and Social Psychology, 51(6), 1173-1182. http://dx.doi.org/10.1037/0022-3514.51.6.1173

Berscheid, E., Snyder, M., \& Omoto, A. M. (1989). The relationship closeness inventory: Assessing the closeness of interpersonal relationships. Journal of Personality and Social Psychology, 57, 792-807. http://dx.doi.org/10.1037/0022-3514.57.5.792

Betzig, L. (1988). Redistribution: Equity or exploitation? In L. Betzig, M. Borgerhoff Mulder, \& P. Turke (Eds.), Human reproductive behaviour: A Darwinian perspective (pp. 49-63). Cambridge: Cambridge University Press.

Betzig, L., \& Turke, P. (1986). Food sharing on Ifaluk. Current Anthropology, 27, 397-400. http://dx.doi.org/10.1086/203457

Burnstein, E., Crandall, C., \& Kitayama, S. (1994). Some neo-Darwinian rules for altruism: Weighing cues for inclusive fitness as a function of the biological importance of the decision. Journal of Personality and Social Psychology, 67, 773-789. http://dx.doi.org/10.1037/0022-3514.67.5.773

Chagnon, N. (1981). Terminological kinship, genealogical relatedness and village fissioning among the Yanomamo Indians. In R. Alexander \& D. Tinkle (Eds.), Natural selection and social behaviour (pp. 490-508). New York: Chiron Press.

Chagnon, N., \& Bugos, P. (1979). Kin selection and conflict: An analysis of a Yanomamo ax fight. In N. Chagnon, \& W. Irons (Eds.), Evolutionary biology and human social behaviour: An anthropological perspective (pp. 213-238). North Scituate, MA: Duxbury.

Cialdini, R. B., Brown, S. L., Lewis, B. P., Luce, C., \& Neuberg, S. L. (1997). Reinterpreting the empathy-altruism relationship: When one into one equals oneness. Journal of Personality and Social Psychology, 73, 481-494. http://dx.doi.org/10.1037/0022-3514.73.3.481

Clark, M. S., \& Lemay, E. P., Jr. (2010). Close relationships. In S. T. Fiske, D. T. Gilbert \& G. Lindzey (Eds.), Handbook of social psychology (5th ed., Vol. 2, pp. 898-940). New York: Wiley. http://dx.doi.org/10.1002/9780470561119.socpsy002025

Clark, M. S., Oullette, R., Powell, M. C., \& Milberg, S. (1987). Recipient's mood, relationship style, and helping. Journal of Personality and Social Psychology, 53, 94-103. http://dx.doi.org/10.1037/0022-3514.53.1.94

Davis, M. H., Conklin, L., Smith, A., \& Luce, C. (1996). Effect of perspective taking on the cognitive representation of persons: A merging of self and other. Journal of Personality and Social Psychology, 70, 713-726. http://dx.doi.org/10.1037/0022-3514.70.4.713

Essock-Vitale, S. M., \& McGuire, M. (1985). Women's lives viewed from an evolutionary perspective: II. Patterns of helping. Ethology and Sociobiology, 6, 155-173. http://dx.doi.org/10.1016/0162-3095(85)90028-7

Flinn, M. V. (1988). Step- and genetic parent/offspring relationships in a Carribean village. Ethnology and Sociobiology, 9, 335-369. http://dx.doi.org/10.1016/0162-3095(88)90026-X

Gunia, B. C., Sivanathan, N., \& Galinsky, A.D. (2009). Vicarious entrapment: Your sunk costs, my escalation of commitment._Journal of Experimental Social Psychology, 45(6), 1238-1244. http://dx.doi.org/10.1016/j.jesp.2009.07.004

Gurven, M., Hill, K., Kaplan, H., Hurtado, A., \& Lyles, R. (2000). Food transfers among Hiwi foragers of Venezuela: tests of reciprocity. Human Ecology, 28(2), 171-218. http://dx.doi.org/10.1023/A:1007067919982

Hames, R. B. (1987). Relatedness and garden labor exchange among the Ye'kwana. Ethology and Sociobiology, 8, 354-392. http://dx.doi.org/10.1016/0162-3095(87)90028-8

Hamilton, W. D. (1964). The genetical evolution of social behaviour: I \& II. Journal of Theoretical Biology, 7 , 1-32. http://dx.doi.org/10.1016/0022-5193(64)90038-4

Hawkes, K. (1983). Kin selection and culture. American Ethnologist, 10, 345-363. http://dx.doi.org/10.1525/ae.1983.10.2.02a00090

Hoffman, M. L. (1981). Is altruism part of human nature? Journal of Personality and Social Psychology, 40. 
Ferolino, A., \& Labaclado, R.

http://dx.doi.org/10.1037/0022-3514.40.1.121

Jaccard, J., \& Turrisi, R. (2003). Interaction effects in multiple regression (2nd ed.). Thousand Oaks, CA: Sage Publications.

Jocano, F. L. (1998). Filipino social organization: Traditional kinship and family organization. Quezon City: Punlad Research House, Inc.

Jose, P. E. (2013). Doing statistical mediation and moderation. New York, NY: Guilford Press.

Kelly, H. H., Berscheid, E., Christensen, A., Harvey, J. H., Huston, T. L., Levinger, G., McClintock, E., Peplau, L. A., \& Peterson, D. R. (1983). Close relationships. New York: W. H. Freeman.

Korchmaros, J. D., \& Kenny, D. A. (2006). An evolutionary and close-relationship model of helping. Journal of Social and Personal Relationships, 23, 21-43. http://dx.doi.org/10.1177/0265407506060176

Korchmaros, J., \& Kenny, D. (2001). Emotional closeness as a mediator of the effect of genetic relatedness on altruism. Psychological Science, 12(3), 262-265. http://dx.doi.org/10.1111/1467-9280.00348

Krebs, D. (1975). Empathy and altruism. Journal of Personality and Social Psychology, 32(6), 1134-1146. http://dx.doi.org/10.1037/0022-3514.32.6.1134

Kruger, D. J. (2003). Evolution and altruism: Combining psychological mediators with naturally selected tendencies. Evolution and Human Behavior, 24, 118-125. http://dx.doi.org/10.1016/S1090-5138(02)00156-3

Krupp, D. B., DeBruine, L. M., \& Barclay, P. (2008). A cue of kinship promotes cooperation for the public good. Evolution and Human Behavior, 29, 49-55. http://dx.doi.org/10.1016/j.evolhumbehav.2007.08.002

Maner, J. K., Luce, C. L., Neuberg, S. L., Cialdini, R. B., Brown, S., \& Sagarin, B. J. (2002). The effects of perspective taking on motivations for helping: Still no evidence for altruism. Personality and Social Psychology Bulletin, 28, 1601-1610. http://dx.doi.org/10.1177/014616702237586

Miralao, V. A. (1997). The family, traditional values and the sociocultural transformation of Philippine Society. Philippine Sociological Review, 45(1/4), 189-215.

Neuberg, S. L., Kenrick, D. T., \& Schaller, M. (2010). Evolutionary social psychology. In S.T. Fiske, D.T. Gilbert, \& G. Lindzey (Eds.), Handbook of Social Psychology (Vol. 2, pp. 761-796). New Jersey: John Wiley \& Sons, Inc. http://dx.doi.org/10.1002/9780470561119.socpsy002021

Neyer, F. J., \& Lang, F. R. (2003). Blood is thicker than water: Kinship orientation across adulthood. Journal of Personality and Social Psychology, 84, 310-321. http://dx.doi.org/10.1037/0022-3514.84.2.310

Park, J., Schaller, M., \& Van Vugt, M. (2008). The psychology of human kin recognition: Heuristic cues, erroneous inferences, and their implications. Review of General Psychology, 12, 215-235. http://dx.doi.org/10.1037/1089-2680.12.3.215

Patton, J. (2005). Meat sharing for coalitional support. Evolution and Human Behavior, 26, 137-157. http://dx.doi.org/10.1016/j.evolhumbehav.2004.08.008

Pollet, T., Roberts, S. G. B., \& Dunbar, R. I. M. (2013). Going that extra mile: Individuals travel further to maintain face-to-face contact with highly related kin than with less related kin. PLoS ONE, 8(1). http://dx.doi.org/10.1371/journal.pone.0053929

Rhee, E., Uleman, J. S., Lee, H. K., \& Roman, R. J. (1995). Spontaneous self-concepts and ethnic identities in individualistic and collectivistic cultures. Journal of Personality and Social Psychology, 69, 142-152. http://dx.doi.org/10.1037/0022-3514.69.1.142

Roberts, G. (2005). Cooperation through interdependence. Animal Behaviour, 70, 901-908. http://dx.doi.org/10.1016/j.anbehav.2005.02.006

Rushton, J. P., Chrisjohn, R. D., \& Fekken, G. C. (1981). The altruistic personality and the self-report altruism scale. Personality and Individual Differences, 2(4), 293-302. http://dx.doi.org/10.1016/0191-8869(81)90084-2

Rushton, J. P., Russell, R. J. H., \& Wells, P. A. (1984). Genetic similarity theory: Beyond kin selection. Behavior Genetics, 14(3), 179-193. http://dx.doi.org/10.1007/BF01065540

Silk, J. B. (2003). Cooperation without counting: The puzzle of friendship. In P. Hammerstein (Ed.), Genetic and cultural evolution of cooperation (pp. 37-54). Cambridge, MA: MIT Press.

Stewart-Williams, S. (2007). Altruism among kin vs. non-kin: Effects of cost of help and reciprocal exchange. 
Evolution and Human Behavior, 28, 193-198. http://dx.doi.org/10.1016/j.evolhumbehav.2007.01.002

Stewart-Williams, S. (2008). Human beings as evolved nepotists: Exceptions to the rue and effects of costs of help. Human Nature, 19, 414-425. http://dx.doi.org/10.1007/s12110-008-9048-y

Toi, M., \& Batson, C. D. (1982). More evidence that empathy is a source of altruistic motivation. Journal of Personality and Social Psychology, 43, 281-292. http://dx.doi.org/10.1037/0022-3514.43.2.281

Tooby, J., \& Cosmides, L. (1996). Friendship and the banker's paradox: Other pathways to the evolution of adaptations for altruism. In W. G. Smith, J. M. Smith (Eds.), Evolution of social behaviour patterns in primates and man (pp. 119-143). London: Oxford University Press.

Tooley, G. A., Karakis, M., Stokes, M., \& Ozanne-Smith, J. (2006). Generalising the Cinderella Effect to unintentional childhood fatalities. Evolution and Human Behavior, 27, 224-230. http://dx.doi.org/10.1016/j.evolhumbehav.2005.10.001

Trivers, R. L. (1971). The evolution of reciprocal altruism. Quarterly Review of Biology, 46, 35-57. http://dx.doi.org/10.1086/406755

Webster, G. D. (2003). Prosocial behaviour in families: Moderators of resource sharing. Journal of Experimental Social Psychology, 39, 644-652. http://dx.doi.org/10.1016/S0022-1031(03)00055-6

Wells, P. A. (1987). Kin recognition in humans. In D. J. C. Fletcher \& C. D. Michener (Eds.), Kin recognition in animals (pp. 395-416). New York: Wiley. 
Ferolino, A., \& Labaclado, R. 